Relations industrielles

Industrial Relations

\title{
Stephen Brooks and Andrew Stritch, Business and Government
} in Canada

\section{Alexander J. Matejko}

Volume 46, numéro 4, 1991

URI : https://id.erudit.org/iderudit/050735ar

DOI : https://doi.org/10.7202/050735ar

Aller au sommaire du numéro

\section{Éditeur(s)}

Département des relations industrielles de l'Université Laval

\section{ISSN}

0034-379X (imprimé)

1703-8138 (numérique)

Découvrir la revue

Citer ce compte rendu

Matejko, A. J. (1991). Compte rendu de [Stephen Brooks and Andrew Stritch, Business and Government in Canada]. Relations industrielles / Industrial Relations, 46(4), 884-885. https://doi.org/10.7202/050735ar

Tous droits réservés (C) Département des relations industrielles de l'Université Laval, 1991
Ce document est protégé par la loi sur le droit d'auteur. L'utilisation des services d'Érudit (y compris la reproduction) est assujettie à sa politique d'utilisation que vous pouvez consulter en ligne.

https://apropos.erudit.org/fr/usagers/politique-dutilisation/ 
Le format du rapport est assez intéressant et en permet une lecture facile: nombreux encarts, présentation aérée, tableaux, etc. Ce rapport s'adresse de façon évidente à des praticiens et praticiennes et compte tenu de cet objectif, $j$ 'estime qu'il donne un aperçu honnête mais très synthétique de ce que l'on sait actuellement de l'expérience ontarienne. À ce titre, ce rapport pourra être utile aux personnes qui n'ont pas été initiées, d'aucune manière, à la situation ontarienne. Pour celles qui ont déjà eu l'occasion de feuilleter la nombreuse documentation publiée par la Commission de l'équité salariale ou par certains syndicats ontariens (CUPE, OFL, etc.), le rapport n'apportera aucun élément nouveau mais il aura au moins eu le mérite de ramasser en un seul endroit une documentation intéressante et ce faisant, de constituer un dossier sommaire sur l'expérience originale et novatrice de notre province voisine.

Esther DÉom

Université Laval

Business and Government in Canada, by Stephen Brooks and Andrew Stritch, Scarborough, Ont., Prentice-Hall of Canada, 1991, xiv + 482 p., ISBN 0-13-098427-2

This is an important book dealing with business-government relations, historical perspective on commerce and industry in Canada, industrial structure, corporate concentration and the business elite, the impact of federalism, business organization and lobbying, business and media, business and political parties, competition policy, business regulation, international trade policy, the Canada-US free trade agreement, industrial relations, business and government in the 1990s, and the machinery of Canadian government. In this review I will limit myself to the summary of what the authors say on industrial relations, as well as to my own comments.

The dynamics of real-world business-government relations includes, among others, industrial relations. The general attitude of Canadian as well as American employers in dealing with unions was traditionally just hostility but in the period 1951-87 union membership in the non-agricultural labour force has grown in Canada from $28 \%$ to $38 \%$ when in the US it has declined from $32 \%$ to $17 \%$. The tripartite problem solving arrangement, based on the compulsory investigation of labour disputes involving public utilities was started by Mackenzie King already in 1907. Since the late 1940s labour's political agenda was increasingly in tune with the mainstream of Canadian attitudes (p. 420) and this had its significant impact on industrial relations, opening room for collective bargaining.

Canadian employers seem to be particularly sensitive about unions allegedly interfering into the owner's right to decide whom they employ and how the business is run. On the other hand, unions are lukewarm regarding any chance to cooperate with the employer. "A union's legal right to bargain collectively with an employer is hollow without the necessary means to persuade workers to support the union and to compel the employer to take the union's demands seriously"' (p. 420). When one out of four people in the labour force are in the public sector, the unionization of that sector during the 1970s has contributed to the growing role of collective bargaining especially because the Rand formula imposes payment of the union dues also on the nonunionized employees.

The debt burden of the governments and the heavy dependence of Canada on the foreign trade (the merchandise exports in \% GDP have grown in the period $1965-89$ from $15 \%$ to $22 \%$, in comparison with $7 \%$ in the US and $10 \%$ in Japan but $28 \%$ in Germany) have both contributed to the growing cost consciousness of the employers. Canadian imports in the period $1965-89$ in $\%$ of GDP have grown from $15 \%$ to $21 \%$ and many imported goods became highly 
competitive with the local products (and services). The competition of foreign cheap labour is a very serious danger for the security of employment and remuneration for the local labour force.

The trust of Canadians into basic institutions is diminishing, and this is primarily valid for government (particularly federal) and trade unions. "The unpopularity of labour unions suggests that there is no groundswell of class sentiment that might challenge the rights of capital. Some industries are viewed negatively by the Canadian public, and many reasons for more regulation of business are supported by it. But overall, there appears to be no grounds for believing that Canadians question either the legitimacy or the effectiveness of their capitalist economic system. The cultural/ideological dominance of business thus appears to be well entrenched"' (p. 445).

The general public is aware of the international economic forces which are difficult, or even maybe impossible to be effectively controlled, and the pressure to rationalise the utilization of labour (including the diminishment of its relative cost), are the measures widely used in order to defend the economy of Canada versus the competitors.

It becomes extremely difficult for the governments to protect domestic producers from foreign competition and at the same time to bring the costs of doing business more into line with what they are in countries jostling for the same investment capital (p. 448). The authors expect a continued growth in the structural power of business, "as governments battle to attract corporate investment in an increasingly mobile and competitive international environment" (p. 449).

From that broad and longitudinal perspective presented by the authors, the promotion of an adversarial relationship between those who sell their labour and those who buy it is selfdefeating in the long run because it contributes to the diminishing chances of Canadians on the international markets. The orientation towards confrontation instead of cooperation is much damaging for all involved partners. The climate in the country growingly unfavourable to the "antagonistic problem solving" in the field of labour relations, and particularly the vital public services, was well illustrated by the decision in 1987 by the Supreme Court of Canada that freedom of association does not necessarily assure the right to bargain collectively and the right to strike. There is much future in Canada for the reinforcement of trust relationships.

The problems of competitiveness and training of the labour force would deserve more attention than it is presented in the book. In the long run it is impossible to win on the international markets without the adequate credentials on all levels: from students being very good in basic reading and writing up to the competitive expectation at the level of graduate studies. Canada in many respects is still a 'lucky' country if taking into consideration that in the period 1960-89, according to recent calculations, the real disposable income and future wealth (retirement money) has grown per household by $70 \%$. On the other hand, any considerable deterioration of the labour force quality, management style, and industrial peace may undermine the achievements, in addition to the endangered unity. The book would gain in insight and importance by addressing even more than it does, the dramatical nature of international challenges to which Canada is constantly exposed (by remaining behind the development of science and modern technology, losing agricultural markets, not expecting enough from university students, not training an adequate number of skilled blue collar workers and technicians, not encouraging competition between various institutions of higher learning, not upgrading enough quality of management in the public sector, etc.).

Alexander J. Matejko 